\title{
Seed biology of rush skeletonweed in sagebrush steppe
}

\author{
JULIA D. LIAO, STEPHEN B. MONSEN, VAL JO ANDERSON, AND NANCY L. SHAW
}

Authors are Ph.D. student, Department of Rangeland Ecology and Management, Texas A\&M University, College Station, Tex.. 77843; botanist, USDA-FS, Rocky Mountain Research Station, Provo, Ut. 84606; associate professor, Botany and Range Science Department, Brigham Young University, Provo, Ut. 84602; and botanist, USDA-FS, Rocky Mountain Research Station, Boise, Ida. 83702. At the time of the research, the senior author was graduate student, Department of Botany and Range Science, Brigham Young University, Provo, Ut. 84602.

\section{Abstract}

Rush skeletonweed (Chondrilla juncea $\mathrm{L}$.) is an invasive, herbaceous, long-lived perennial species of Eurasian or Mediterranean origin now occurring in many locations throughout the world. In the United States, it occupies over 2.5 million ha of rangeland in the Pacific Northwest and California. Despite the ecological and economic significance of this species, little is known of the ecology and life history characteristics of North American populations. The purpose of this study was to examine seed germination characteristics of 2 populations of rush skeletonweed in Idaho. Seeds from rush skeletonweed plants in southwestern Idaho were collected during the 1994 and 1995 growing seasons. Mature seeds were harvested on 6 dates between early July and early October 1994, and on 5 dates between early July and late September 1995. Fresh seeds from each harvest period were measured to determine seed weight, total germination, rate of germination, and viability (tetrazolium staining [TZ]) of non-germinating seeds. An aliquot of seeds collected in 1994 was also stored for 1 year to examine the effects of seed storage on germination. In southwestern Idaho, rush skeletonweed produces seeds continuously from mid-July through October. Seeds were capable of immediate germination without scarification or wet prechilling. Total germination generally ranged from 60 to $100 \%$ throughout the entire seed production period. Germination was also rapid, reaching $50 \%$ of total germination in less than 12 days. In general, germination was higher at the lower incubation temperature regime $\left(20 / 10^{\circ} \mathrm{C}\right)$, perhaps reflecting origins of this species in Mediterranean winter rainfall regions. The TZ testing indicated that 30 to $60 \%$ of non-germinating seeds were viable, suggesting that seeds may persist in the soil seed bank. Up to $60 \%$ of seeds remained viable following 1 year of storage. Stored seeds generally exhibited higher germination rates $(\overline{\mathbf{x}}=90 \%)$ than fresh seeds $(\bar{x}=67 \%)$, indicating possible dormancy and afterripening effects. Germination characteristics of this species are consistent with those of other invasive alien species, and favor rapid population growth leading to community dominance.

Key Words: Chondrilla juncea L., Pacific Northwest, rangeland weed, cereal crop weed, invasive species, germination

The authors wish to thank Beth-Anee Johnson, Mering Hurd, Danielle Scholten, Kristi Worth, and Fred Galen for their help in data collection. We would like to thank Dr. Michael Longnecker for assistance with statistical analysis and Dr. Thomas W. Boutton and Dr. Marshall Haferkamp for manuscript review. We thank the USDA-FS, Rocky Mountain Research Station, Shrub Sciences Laboratory, and USDI-BLM, Idaho State Office for funding, support, and use of facilities and equipment. Partial support for manuscript preparation was provided by the Department of Rangeland Ecology and Management at Texas A\&M University.

Manuscript accepted 5 Dec. 1999.

\section{Resumen}

Chondrilla juncea L. (nombre vulgar: yuyo esqueletico) es una especie herbácea perenne e invasora de larga vida y origen eurasiático o mediterraneo que habita actualmente en muchos lugares del mundo. En los Estados Unidos, ocupa más de 2.5 millones de hectáreas de tierras ganaderas en el Noroeste Pacífico y California. A pesar del significado ecológico y económico de esta especie, poco se sabe sobre la ecología y las características de la historia de vida de las poblaciones norteamericanas. El objetivo del presente trabajo fue examinar las características de la germinación de semillas de dos poblaciones de $C$. juncea en Idaho. Se colectaron semillas de plantas en el suroeste de Idaho durante la estación de crecimiento en 1994 y 1995. Se coleccionaron semillas maduras en 6 ocasiones entre principios de julio y principios de octubre de 1994, y en 5 ocasiones entre principios de julio y fines de septiembre de 1995. Se midieron semillas frescas de cada cosecha para determinar el peso de las semillas, la germinación total, la tasa de germinación, y la viabilidad (teñido con tetrazolio [TZ]) de semillas que no germinaron. Una alícuota de semillas colectadas en 1994 se almacenó por un año para examinar los efectos del almacenamiento sobre la germinación. En el suroeste de Idaho, $C$. juncea produce semillas continuamente desde mediados de julio hasta octubre. Las semillas fueron capaces de germinar inmediatamente sin escarificación o mojado y enfriado previos. La germinación total varió generalmente del 60 al $100 \%$ durante el período completo de producción de semillas. La germinación también fue rápida, alcanzando el $50 \%$ de la germinación total en menos de 12 días. En general, la germinación fue mayor en el régimen de temperatura de incubación más bajo $\left(20 / 10^{\circ} \mathrm{C}\right)$, lo cual quizás refleja el origen de esta especie en regiones mediterraneas de lluvias invernales. Las pruebas con TZ indicaron que del 30 al $60 \%$ de las semillas que no germinaron eran viables, sugeriendo que las semillas podrían persistir en el banco de semillas. Hasta el $60 \%$ de las semillas seguían viables después de un año de almacenamiento. Las semillas almacenadas generalmente mostraron proporciones de germinación mayores $(\overline{\mathbf{x}}=90 \%)$ que las frescas $(\overline{\mathbf{x}}=67 \%)$, indicando posibles efectos de la dormancia y postmaduración. Características de germinación de esta especie son consistentes con las de otras especies exóticas invasoras, y favorecen un crecimiento rápido de las poblaciones que la lleva a dominar en la comunidad.

Rush skeletonweed (Chondrilla juncea L., Asteraceae: Cichorieae), an apomictic, perennial forb with Eurasian and Mediterranean origins, has been introduced to other regions of the world, including Australia, South America, and the United 
States (Cullen and Groves 1977, McVean 1966, Panetta and Dodd 1987). In North America, it was first discovered in the Wash. in 1938. By 1981, its rate of spread was approximately 40,000 ha year ${ }^{-1}$ (Cheney et al. 1981). It now dominates more than 2.5 million ha of rangeland in the Pacific Northwest and California (Sheley and Hudak 1995).

Rush skeletonweed grows in dense monocultures and displaces native plants, thereby reducing biodiversity and forage production for both domestic and native herbivores (Carroll 1980, Sheley and Hudak 1995). Seeds are wind-dispersed. New infestations establish on coarse, welldrained soils along roadways and on overgrazed rangelands, abandoned croplands, and other disturbed sites. The species exhibits a wide range of adaptability, occurring at elevations from less than 225 $\mathrm{m}$ to over $1,830 \mathrm{~m}$ that receive 250 to $1,500 \mathrm{~mm}$ annual precipitation (Moore 1964, Sheley and Hudak 1995).

Although rush skeletonweed is spreading primarily on rangelands, its potential threat to agricultural crops is also a major concern as it competes aggressively for light, water, and nutrients (Schirman and Robocker 1967, Zimdahl 1980). In some parts of Oregon and northern Idaho, rush skeletonweed has reduced annual wheat western United States near Spokane,

yields by 26 to $42 \%$ (Cheney et al. 1981). It is one of the most serious weeds of cereal cropping in Australia where it has reduced wheat yields by as much as $80 \%$ (Piper 1983, Sheley and Hudak 1995, Sheley et al. 1999).

Current technology is largely ineffective at curtailing the spread of rush skeletonweed. Although the weedy characteristics of Australian populations have been described, a better understanding of the reproductive potential and germination characteristics of North American populations is essential if we are to identify the biological characteristics that contribute to the ecological success of this species, and develop more effective management methods (Wapshere et al. 1974, Lee 1986, Sheley et al. 1999). The objective of this study was to evaluate the effects of environmental conditions, maturation date, and dry storage on seed germination and viability of 2 rush skeletonweed populations in southwestern Idaho.

\section{Materials and Methods}

\section{Study Sites}

Populations of rush skeletonweed were identified at 2 locations in southwestern Idaho. The Orchard Research Site

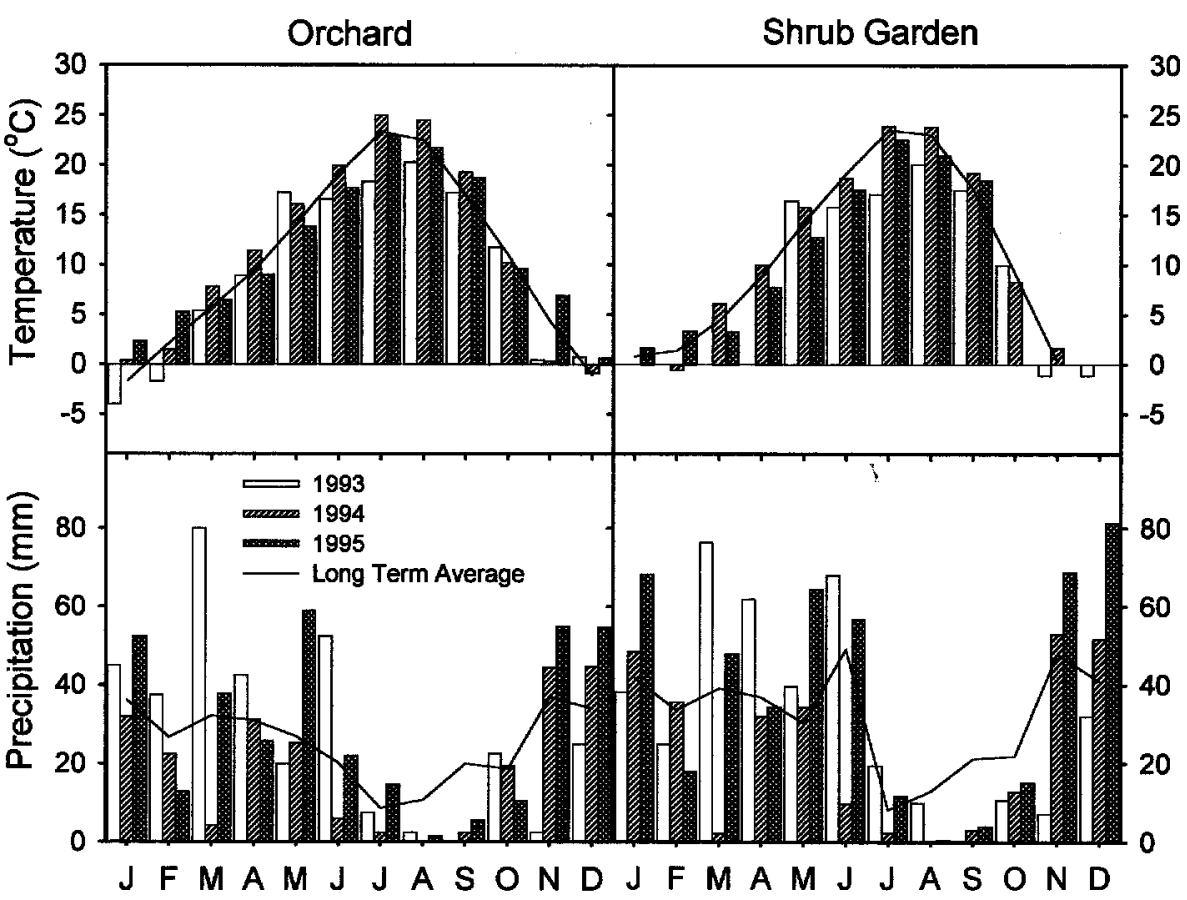

Fig. 1. Air temperature and precipitation profiles for the Orchard and Shrub Garden sites, 1993-1995. Climatic data were based on NOAA information from the Boise Airport (Orchard) and Lucky Peak (Shrub Garden) Idaho weather stations. Long term averages encompass 1961-1990. (NOAA 1993, 1994, 1995).
(Orchard) is located $32 \mathrm{~km}$ southeast of Boise, Ada Co., Ida. (116 04' W $43^{\circ} 33^{\prime}$ $\mathrm{N})$, at an elevation of $955 \mathrm{~m}$ (NOAA 1993, Kitchen 1995). Mean annual temperature is $10.5^{\circ} \mathrm{C}$. (Fig. 1) (NOAA 1993). Mean annual precipitation is $250 \mathrm{~mm}$ with $81 \%$ occurring between November and June (Fig. 1). The frost-free period ranges from 140 to 190 days. This site supports a degraded Wyoming big sagebrush (Artemisia tridentata Nutt. var. wyomingensis [Beetle \& A. Young] Welsh)/mixed bunchgrass community. Soils are sandy, mixed, mesic Xeric Torriorthents with deep, well-drained profiles. The rooting zone extends to a depth of $1.5 \mathrm{~m}$ or more and available water capacity is high (Collett 1980)

The Shrub Garden site is located near the Boise River, about $27 \mathrm{~km}$ northeast of Boise, Ada Co., Ida. (116 04' W 43 $33^{\prime}$ $\mathrm{N})$, at an elevation of $1,033 \mathrm{~m}$. Mean annual temperature is $9.2^{\circ} \mathrm{C}$ (Fig. 1) (NOAA 1993). Mean annual precipitation is $430 \mathrm{~mm}$, and the frost-free period averages 126 days (Fig. 1). The site supports an antelope bitterbrush (Purshia tridentata [Pursh] DC.)/mountain big sagebrush (Artemisia tridentata Nutt. var. vaseyana [Rydb.] J. Boivin) community with a diverse grass-forb understory (Shaw and Monsen 1982). Soils are loamy-skeletal, mixed, mesic Aridic Argixerolls that are moderately deep and well-drained, developing from weathered granite (Collett 1980).

\section{Seed Collection and Testing}

Sixty plants at each study location were randomly selected and marked for seed collection in spring 1994. Mature seeds were hand harvested at 2-week intervals from the time of earliest maturation in late July through early October in 1994. In 1995 , seeds were harvested on days within the same 7-day periods as in 1994, with the exception that no collections were made in October 1995. Weeks of harvest were: late July (22 to 28), early August (6 to 12), late August (18 to 24), early September (3 to 9), late September (22 to 29 ), and early October (7 to 13). Seeds were pooled among plants within a location on each harvest date.

Seeds were cleaned by hand-rubbing and sieving to remove the pappus and debris. Subsamples of each cleaned seed lot were used to determine seed weight, germinability, and viability. On each collection date, 3 subsamples of 100 seeds from each location were weighed to estimate average seed weight. Three additional subsamples of 100 seeds from each 
location were immediately placed in incubation trials (1 to 2 days after collection). Remaining seeds from each 1994 collection date not used in germination trials were stored in sealed glass containers at room temperature in darkness for a period of about 1 year. Three subsamples of 100 stored seeds from each location and collection date were placed in incubation about 1 year later in late August 1995 to examine the effects of dry storage on seed germination characteristics. Because the effects of storage on seed germination were only examined for seed produced in a single growing season (1994), inferences are not broadly applicable to seed generated in another year.

Germination trials were conducted by placing each subsample of 100 seeds on 2 blue blotters saturated with distilled water in an $11 \times 11 \mathrm{~cm}$ germination box. Germination boxes were then incubated at either $20 / 10$ or $30 / 20^{\circ} \mathrm{C}$ (12 hrs/12 hrs). Seeds were exposed to light $(\mathrm{PAR}=15$ $\left.\mu \mathrm{M} \mathrm{m}^{-2} \mathrm{~s}^{-1}\right)$ during the high temperature alteration. Germination counts were made at 2-day intervals for 14 days. Germination boxes were rearranged randomly in the incubation chambers after each count. Seeds were considered germinated when the radicle had emerged and the cotyledons were green and spreading. After 14 days, non-germinated seeds were tested for viability using a $1 \%$ solution of 2,3,5-triphenyl tetrazolium chloride (Moore 1973). Maximum germination was calculated as number of seeds germinated divided by the number of germinated seeds plus the number of viable nongerminated seeds determined by TZ testing. Rate of germination was expressed as days to $50 \%$ of 14-day germination.

\section{Statistical Analyses}

Experimental design was a randomized, complete block with site as the blocking factor. An ANOVA was used to evaluate differences in germination, germination rate, and viability of nongerminated fresh and stored seeds attributable to the main effects of year of collection, harvest date, storage treatment, and incubation regime and all possible interactions (SAS Institute 1988). Where significant interactions precluded direct interpretation of main effects, pairwise comparisons were made using the Bonferroni t-test (Milliken and Johnson 1992). All differences reported were significant at $\mathrm{p} \leq 0.05$. Regression analyses were used to examine the relationship between seed weight and environmental conditions preceding each harvest date, germination, and rate of germination.

\section{Results}

\section{Climatic Conditions}

Total 1994 precipitation was $4 \%$ below average at Orchard and 33\% below average at the Shrub Garden (Fig. 1). By contrast, 1995 was a relatively wet year. Total precipitation was $43 \%$ above average at Orchard and $12 \%$ above average at the Shrub Garden. In 1994 and 1995, the 14day mean maximum air temperature prior to each harvest date ranged from 27 to $32^{\circ} \mathrm{C}$ at both locations, while the mean 14day minimum air temperature ranged from 8 to $16^{\circ} \mathrm{C}$.

\section{Seed Weight}

Weight of individual rush skeletonweed seeds ranged from 0.1 to $0.5 \mathrm{mg}$ (Fig. 2). Seed weight was greater in 1994 than in 1995 for the early harvest dates $(\mathrm{p}<0.01)$ (Fig. 2). In 1994, seed weight was positively correlated with total precipitation received during the 4-week interval prior to each harvest date $\left(\mathrm{R}^{2}=0.75, \mathrm{p}<0.05\right)$ and with the mean air temperature during the 2week period preceding each harvest date $\left(\mathrm{R}^{2}=0.98, \mathrm{p}<0.05\right)$. No significant correlations between seed weight and precipitation or air temperature were found in 1995.

\section{Germination of Fresh 1994 and 1995 Seeds}

Germination of fresh seeds varied with year of collection, harvest date, and incu- bation regime (Fig. 3A) (Table 1). Seeds collected in early August exhibited lower total germination percentages than seeds collected on other harvest dates. Total germination percentage was not affected by incubation regime in 1994. However, total germination percentage of seeds collected on 1995 harvest dates was greater when incubated at the $20 / 10^{\circ} \mathrm{C}$ compared to the $30 / 20^{\circ} \mathrm{C}$ regime.

Fresh seeds harvested in 1994 and 1995 germinated rapidly, generally reaching $50 \%$ germination within 2 to 8 days (Fig. 3B). Germination rate was affected by a significant 3-way interaction between collection year, week of harvest, and incubation temperature (Table 1).

Days to $50 \%$ germination was similar for seeds harvested on the early dates in 1994 and incubated at either $20 / 10^{\circ} \mathrm{C}$ or $30 / 20^{\circ} \mathrm{C}$. In 1995 , seeds collected on the late harvest dates germinated more rapidly when incubated at $20 / 10^{\circ} \mathrm{C}$ compared to $30 / 20^{\circ} \mathrm{C}$. In both 1994 and 1995 rate of germination was more rapid for seeds collected later in the season and incubated at $20 / 10^{\circ} \mathrm{C}$. There were no significant relationships between seed weight and total germination percentage or germination rate.

Viability of nongerminating seeds differed between years (Table 1). In 1994 less than $10 \%$ of the nongerminating seed were viable following incubation, while in 1995 more than $30 \%$ were viable (Fig. 3C).

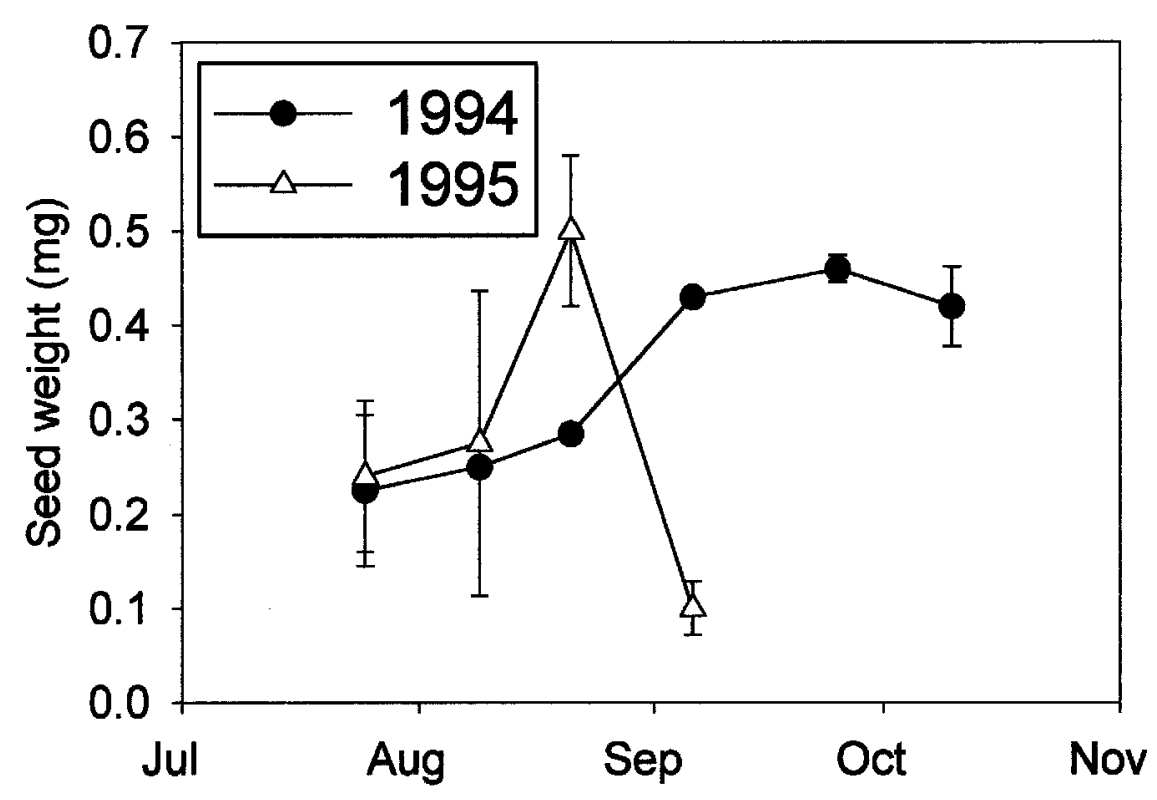

Fig. 2. Mean weight of Chondrilla juncea L. seed (mg) collected on 1994 and 1995 harvest dates from the Orchard and Shrub Garden sites in southwestern Idaho. 
Table 1. Degrees of freedom (df), MS values, and probability levels (p) for ANOVA models used to statistically analyze total germination, days to $50 \%$ germination, and viability [TZ] of nongerminating fresh rush skeletonweed seed from 1994 and 1995 harvest dates and for fresh and stored seed from 1994 harvest dates in southwestern Idaho. Seeds were stored in sealed containers at room temperature from harvest to August 1995.

\begin{tabular}{|c|c|c|c|c|c|c|c|}
\hline \multirow[b]{2}{*}{ Model } & \multicolumn{3}{|c|}{ Total Germination } & \multicolumn{2}{|c|}{$\begin{array}{l}\text { Days to } 50 \% \\
\text { Germination } \\
\end{array}$} & \multicolumn{2}{|c|}{ Viability } \\
\hline & $\mathrm{df}$ & MS & $\overline{\mathrm{p}}$ & $\overline{\mathrm{MS}}$ & $\mathrm{p}$ & MS & $\mathrm{p}$ \\
\hline & & - . - . - & h 199 & s fresh & 5 seed - & - . . . - & - - \\
\hline Collection Site (Block) & 1 & 167.6 & $*$ & 5.9 & $\mathrm{~ns}$ & 562.6 & $*$ \\
\hline Year of Collection (Year) & 1 & 1879.9 & $* * *$ & 18.7 & $*$ & 8444.5 & $* * *$ \\
\hline Week of Collection (Date) & 4 & 1025.0 & $* * *$ & 83.7 & $* * *$ & 117.8 & ns \\
\hline Germination Temperature (Temp) & 1 & 894.3 & $* * *$ & 6.4 & ns & 101.2 & ns \\
\hline Year*Date & 4 & 452.4 & $* * *$ & 12.3 & $* *$ & 105.0 & ns \\
\hline Year*Temp & 1 & 980.1 & $* * *$ & 28.9 & $* * *$ & 160.6 & ns \\
\hline Date*Temp & 4 & 105.3 & ns & 0.9 & ns & 73.7 & ns \\
\hline Year*Date*Temp & 4 & 134.4 & $*$ & 6.1 & $*$ & 25.4 & ns \\
\hline Collection Site (Block) & 1 & 121.8 & $\begin{array}{l}\text { h } 199 \\
\text { ns }\end{array}$ & $\begin{array}{c}\text { S store } \\
1.6\end{array}$ & $\begin{array}{l}94 \text { seed } \\
\text { ns }\end{array}$ & 266.0 & ns \\
\hline Week of Collection (Date) & 5 & 480.8 & $*$ & 31.1 & $* * *$ & 198.7 & $\mathrm{~ns}$ \\
\hline Germination Temperature (Temp) & 1 & 154.8 & ns & 0.6 & ns & 0.0 & ns \\
\hline Storage & 1 & 150.7 & ns & 60.7 & $* * *$ & 351.4 & ns \\
\hline Date*Temp & 5 & 31.2 & ns & 0.7 & ns & 198.2 & $\mathrm{~ns}$ \\
\hline Date*Storage & 5 & 229.2 & ns & 24.4 & $* * *$ & 210.7 & $\mathrm{~ns}$ \\
\hline Temp*Storage & 1 & 196.8 & ns & 22.3 & $*$ & 10.6 & ns \\
\hline Date*Temp*Storage & 5 & 28.8 & ns & 3.9 & ns & 159.6 & ns \\
\hline
\end{tabular}

\section{Germination of Fresh and Stored 1994 Seeds}

Total germination percentage of seeds harvested in 1994 and incubated immediately or stored in sealed containers at room temperature until August 1995 varied with harvest date (Table 1). For stored seeds, those collected mid-season exhibited greater total germination percentages than collections harvested at earlier or later collection periods (Fig. 3D). Stored seeds were as germinable as fresh seed, generally exceeding $80 \%$ germination following 1 year of dry storage.

Days to 50\% germination for 1994 seeds varied with storage treatment and harvest date (Table 1). Stored seeds generally germinated more rapidly than fresh seeds with the exception of seeds collected at the later harvest dates and incubated at $30 / 20^{\circ} \mathrm{C}$ ( Fig. 3E). Days to $50 \%$ germination also varied with storage treatment and incubation regime (Table 1). The germination rate was similar for fresh or stored seeds when incubated at $30 / 20^{\circ} \mathrm{C}$. However, stored seeds germinated more rapidly than fresh seeds when incubated at $20 / 10^{\circ} \mathrm{C}$. The viability of nongerminating seeds was similar for fresh and stored 1994 seed collections averaging 13\% (Table 1). both temperatures tested. Most seeds were capable of immediate germination without pretreatment to relieve dormancy. In both years, seeds reached total germination percentages in excess of $60 \%$ regardless of incubation regime.

Grant-Lipp (1966) reported that rush skeletonweed seeds from Canberra, Australia reached $90 \%$ germination within 24 hours when incubated at temperatures between 18 and $30^{\circ} \mathrm{C}$. Germination was complete within 48 hours. Slower rates reported in this study were attributed to differences in criteria used to define successful germination. Radicle emergence was used by Grant-Lipp; criteria used for this study were believed to provide a more realistic index of seedling survival in the field.

Even in the drier year (1994) when precipitation was considerably less than the 30 year average, rush skeletonweed produced seeds that were highly germinable, reaching total germination percentages generally in excess of $80 \%$ (Fig. 3A). These seeds also exhibited more rapid germination than seeds from 1995. Studies have found that when subjected to mild drought stress, some plant species display higher germinability (Hilhorst and Toorop 1997). Dodd and Panetta (1987) found that a large numbers of seeds are produced even under drought conditions. Rush skeletonweed may be producing viable seeds even under hot, dry conditions because flowering and seed production are independent of summer rainfall (Panetta and Dodd 1987). Plants acquire soil water through deep roots that may penetrate several meters into the soil profile (Panetta and Dodd 1984, 1987). Elevated temperatures during the seed production period in 1994 may have increased the germinability of rush skeletonweed seeds in this study.

In both years, across all dates, there appeared to be a trend toward greater germination rates and faster germination at the lower incubation temperature regime (Fig. 3). Germination of rush skeletonweed seeds was generally rapid in both incubation regimes. Plants reached $50 \%$ of total germination within 2 to 8 days for most dates in both 1994 and 1995. For seeds produced in 1995, germination was slower for seeds incubated at the higher temperature regime. This trend may reflect origins of rush skeletonweed in Mediterranean winter rainfall regions where cool-season germination may ensure access to winter precipitation. The ability to germinate during the cooler portions of the growing season would be advantageous throughout 


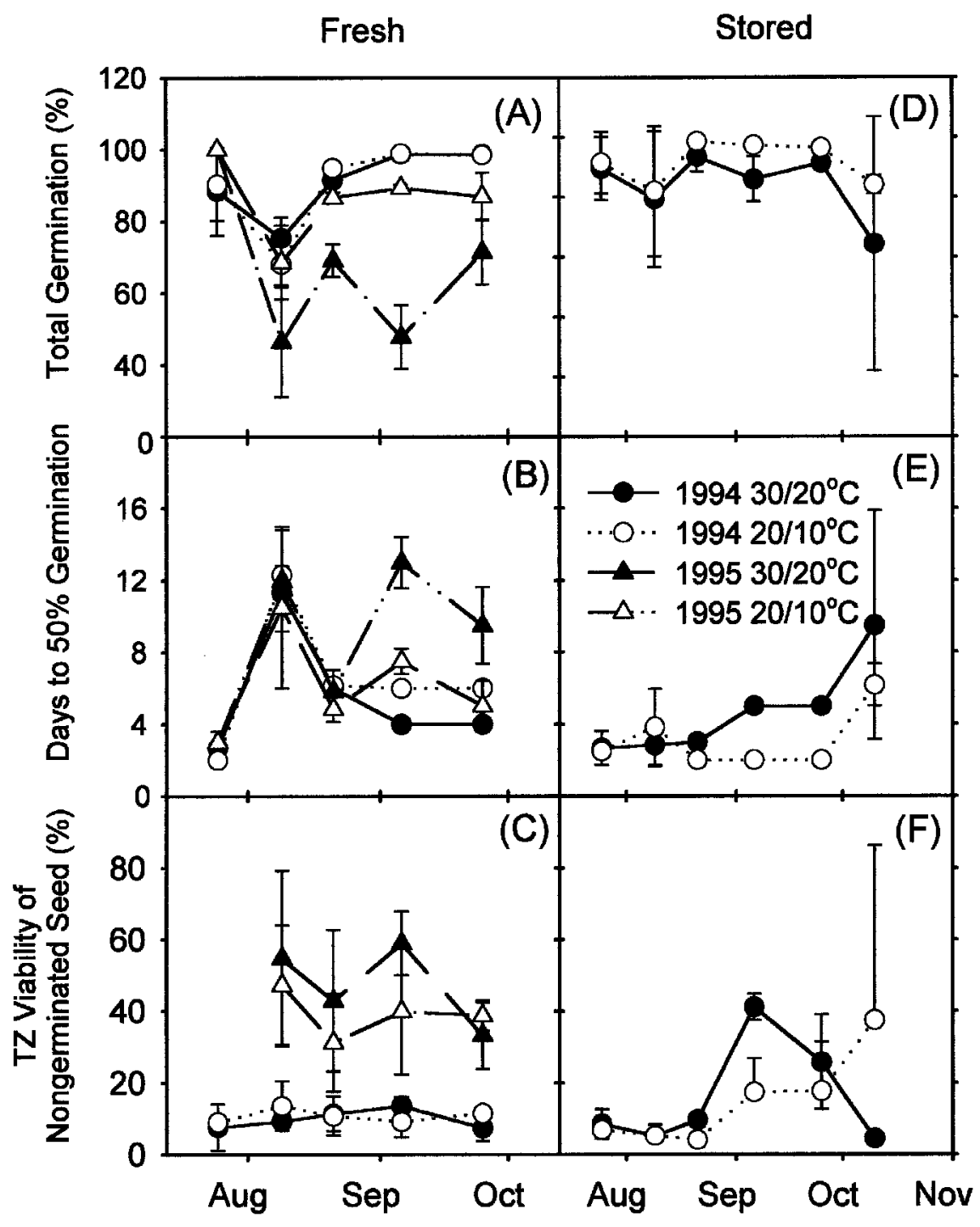

Fig. 3. Germination, germination rate, and viability of non-germinated rush skeletonweed seeds immediately following 1994 and 1995 harvest dates from the Orchard and Shrub Garden sites in southwestern Idaho. The legend in figure 3E applies to the entire graph. Figures 3A, B, and C are results for fresh seed incubated in 1994 and 1995 . The effects of storage on germination were evaluated for seed collected in 1994 only. Figures 3D, E, and F represent results of stored seed collected in 1994 and germinated in August 1995.

much of the northwestern United States where most precipitation occurs during the winter. Conversely, lower germination at higher temperatures may reduce the risk of germination during the warmest, driest portion of the season when soil moisture may be insufficient for seedling survival, establishment, and growth (Baskin and Baskin 1985).

About $10 \%$ of non-germinating seeds from 1994 and more than $30 \%$ of nongerminating seeds from 1995 were viable. Viability of non-germinating seeds may be an indication of some seeds possessing a primary dormancy. Germination results from seeds collected in 1994 and stored for 1 year indicated that storage did not
(Grant-Lipp 1966, McVean 1966, Cuthbertson 1970, Panetta and Dodd 1987). Cuthbertson (1970) stated that there appeared to be a short-lived dormancy in some field samples, while others suggest that rush skeletonweed seeds lack primary dormancy (Grant-Lipp 1966, Coleman-Harrell et al. 1979). Rush skeletonweed seeds may be exhibiting germination polymorphism, a common characteristic of successful weeds. It may be a survival strategy whereby the range of conditions favorable for germination varies among seeds. This mechanism permits some seeds to germinate immediately whereas others may germinate at a later date (Pimentel 1986).

A small percentage of non-germinating stored seeds, especially seeds produced later in the season, were still viable, indicating that rush skeletonweed seeds may acquire a secondary dormancy which could potentially enable some seeds to persist in the soil seed bank. Lonsdale et al. (1988) stated that persistence of seeds in soil seed banks is a critical component for maintaining populations of weedy species. Grant-Lipp (1966) indicated that rush skeletonweed seeds may acquire a secondary dormancy when exposed to high temperatures. Other studies have found that in some plant species, dispersed seeds are readily germinable immediately after shedding, if conditions are favorable. However, when conditions for germination are not met, seeds may acquire a secondary dormancy (Hilhorst and Toorop 1997). Subjecting rush skeletonweed seeds collected in 1994 to storage conditions may have induced a secondary dormancy in some seeds. The findings in this study suggest that a portion of rush skeletonweed seeds may have a primary dormancy and that others may be acquiring a secondary dormancy, enabling seeds to persist in the soil.

In addition to germination polymorphism, rush skeletonweed seeds also showed seed polymorphism in producing seeds of different weights. Although seed weight is positively correlated with germinability in many plant species (Saner et al. 1995), this relationship was not evident with rush skeletonweed in this study.

Seed weight was positively correlated with both temperature and rainfall during the growing season in 1994, but not in 1995. Because 1995 was a wetter year, environmental conditions may have been conducive to greater seedling establishment in the earlier portions of the growing season. Rush skeletonweed density was obviously higher in 1995 than in 1994 
(personal observation). We speculate that plants establishing early in the 1995 growing season may have allocated more carbon to growth while conditions were favorable. However, those plants may have experienced greater intraspecific competition in the latter portion of the growing season when hot, dry conditions ensued. This may have in turn reduced the amount of carbon available for plants to allocate to seed production.

In conclusion, we found that germination characteristics of rush skeletonweed were consistent with those of other successful alien invaders. Rapid germination, without any afterripening requirements, favors rapid explosive population growth and allows rush skeletonweed to spread, persist, and dominate disturbed communities. Secondary dormancy may allow some skeletonweed seed to persist in the soil and possibly reestablish a stand if unfavorable environmental conditions or management activities eliminate an initial population. Due to these characteristics, the control or eradication of rush skeletonweed in most infested areas may prove difficult.

\section{Literature Cited}

Baker, H.G. 1986. Patterns of plant invasion in North America, p. 44-55. In: H.A. Mooney and J.A. Drake (eds.), Ecology of biological invasions of North America and Hawaii. Vol. 58. Springer-Verlag, N.Y., Inc., N.Y.

Baskin, J.M. and C.C. Baskin. 1985. The annual dormancy cycle in buried weed seeds: a continuum. Bioscience 35:492-498.

Bazazz, F.A. 1986. Life history of colonizing plants: some demographic, genetic, and physiological features, p. 96-108. In: H.A. Mooney and J.A. Drake (eds.), Ecology of biological invasions of North America and Hawaii. Vol. 58. Springer-Verlag, N.Y., Inc., N.Y.

Beckstead, J., S.E. Meyer, and P.S. Allen. 1995. Effects of afterripening on cheatgrass (Bromus tectorum) and squirreltail (Elymus elymoides) germination, p. 165-172. In: B.A. Roundy, E.D. McArthur, J.S. Haley, and D.K. Mann (compilers), Proc. Wildland shrub and arid land restoration symposium. USDA For. Serv. INT-GTR-315. Ogden, Ut.

Carroll, P. 1980. Wiry skeletonweed threatens Oregon agriculture, rangelands. Rangelands $2: 21$.

Cheney, T.M., G.L. Piper, G.A. Lee, W.F. Barr, D.C. Thill, R.B. Hawkes, R.F. Line, R.R. Old, L.L. Craft Jr., and E.B. Adams. 1981. Rush skeleton weed biology and control in the Pacific Northwest. Univ. Idaho, Coll. Agr., Cooperative Ext. Serv., Curr. Information Ser. 585. Moscow, Ida.
Coleman-Harrell, M., D. Ehrensing, G. Lee, W. Belles, D. Issacson, and R. Schirman. 1979. Rush skeletonweed. Univ. Idaho, College Agr., Cooperative Ext. Serv., Curr. Information Ser. 468. Moscow, Ida.

Collett, R.A. 1980. Soil survey of Ada County area, Idaho. USDA-SCS, Washington, D.C.

Cullen, J.M. and R.H. Groves. 1977. The population biology of Chondrilla juncea in Australia. Proc. Ecol. Soc. Aust. 10:121-134.

Cuthbertson, E.G. 1970. Chondrilla juncea in Australia 3. Seed maturity and other factors affecting germination and establishment. Aust. J. Exp. Agr. Anim. Husb. 10:62-66.

Dodd, J. and F.D. Panetta. 1987. Seed production by skeletonweed in Western Australia in relation to summer drought. Aust. J. Agr. Res. 38:689-705.

Duke, S.O. 1985. Weed physiology. Vol. I. Reproduction and ecophysiology. CRC Press, Inc. Boca Raton, Fla.

Grant-Lipp, A.E. 1966. Some properties of the seeds of skeletonweed (Chondrilla juncea L.). CSIRO Division of Plant Industry. 5:17-24. Canberra, Aust.

Hilhorst, H.W.M. and P.E. Toorop. 1997. Review on dormancy, germinability, and germination in crop and weed seeds. Adv. Agron. 61:111-165.

Kitchen, S.G. 1995. Return of the native: a look at select accessions of North American Lewis flax, p. 321-326. In: B.A. Roundy, E.D. McArthur, J.S. Haley, and D.K. Mann (compilers), Proc. Wildland shrub and arid land restoration symposium. USDA For. Serv. INT-GTR-315. Ogden, Ut.

Lee, G.A. 1986. Integrated control of rush skeletonweed in the western U.S. Weed Sci. $34: 2-6$.

Lonsdale, W.M., K.L.S. Harley, and J.D. Gillett. 1988. Seed bank dynamics in Mimosa pigra, an invasive tropical shrub. J. Appl. Ecol. 25:963-976.

Mack, R.N. 1986. Alien plant invasion into the Intermountain West; a case history, p.191210. In: H.A. Mooney and J.A. Drake (eds.), Vol. 58. Ecology of biological invasions of North America and Hawaii. Springer-Verlag, New York, Inc., New York.

McVean, D.N. 1966. Ecology of Chondrilla juncea L. in south-eastern Australia. J. Ecol. 54:345-365.

Milliken, G.A. and D.T. Johnson 1992. Analysis of messy data. Vol. 1: Designed experiments. Chapman and Hall, N.Y.

Moore, R.M. 1964. Chondrilla juncea L. (skeleton weed) in Australia. Proc. 7th British Weed Control Conference, p. 563-568.

Moore, R.P. 1973. Tetrazolium staining for assessing seed quality. In: W. Heydecker (ed.), Seed Ecology. Butterworths, London.

NOAA. 1993. Climatological data annual summary Idaho Vol. 96. National Oceanic and Atmospheric Administration, Asheville, N.C.

NOAA. 1994. Climatological data annual summary Idaho. Vol. 97. National Oceanic and Atmospheric Administration, Asheville, N.C.
NOAA. 1995. Climatological data annual summary Idaho. Vol. 98. National Oceanic and Atmospheric Administration, Asheville, N.C.

Panetta, F.D. and J. Dodd. 1984. Skeletonweed: how serious a threat in Western Australia? West. Aust. J. Agr. 25:37-41.

Panetta, F.D. and J. Dodd. 1987. The biology of Australian weeds 16. Chondrilla juncea L. J. Aust. Inst. Agr. Sci. 53:83-95.

Pimentel, D. 1986. Biological invasions of plants and animals in agriculture and forestry, p.149-160. In: H.A. Mooney and J.A. Drake (eds.), Vol. 58. Ecology of biological invasions of North America and Hawaii. Springer-Verlag N.Y., Inc., N.Y.

Piper, G.L. 1983. Rush skeletonweed. Weeds Today 14:5-7.

Saner, M.A., D.R. Clements, M.R. Hall, D.J. Doohan, and C.W. Crompton. 1995. The biology of Canadian weeds. 105. Linaria vul garis Mill. Can. J. Plant Sci. 75:525-537.

SAS Institute. 1988. SAS/STAT User's guide (Release 6.03). SAS Institute, Inc., Cary, N.C.

Schirman, R. and W.C. Robocker. 1967. Rush skeletonweed-threat to dryland agriculture. Weeds 15: 310-312.

Shaw, N.L. and S.B. Monsen. 1982. Phenology and growth habits of nine antelope bitterbrush, desert bitterbrush, stansbury cliffrose, and Apache-plume accessions, p.55-69. In:USDA For. Serv. INT-GTR-152. Ogden, Ut.

Sheley, R.L. and J.M. Hudak. 1995. Rush skeletonweed: a threat to Montana's agriculture. EB 132. Mont. State Univ., Bozeman, Mont.

Sheley, R.L., J.M. Hudak, and R.T. Grubb. 1999. Rush skeletonweed. In: R.L. Sheley and J.K. Petroff (eds.), Biology and management of noxious rangeland weeds. Ore. State Univ. Press, Corvallis, Ore.

Wapshere, A.J., S. Hasan, W.K. Wahba, and L. Caresche. 1974. The ecology of Chondrilla juncea in the western Mediterranean. J. Appl. Ecol. 11: 783-800.

Zimdahl, R.L. 1980. Weed crop competition. Int. Plant Protection Center, Corvallis, Ore. 